Original article

\title{
Nutritional therapy and outcomes in underweight critically ill patients
}

\author{
Marina V. Viana ${ }^{\text {a, }}{ }^{*}$, Ana Laura Tavares ${ }^{\text {b }}$, Luiza A. Gross ${ }^{b}$, Tiago Antonio Tonietto ${ }^{\text {c, a }}$, \\ Vicente L. Costa ${ }^{\text {b }}$, Rafael B. Moraes ${ }^{a}$, Mirela J. Azevedo ${ }^{\mathrm{d}}$, Luciana V. Viana ${ }^{\mathrm{d}}$ \\ ${ }^{a}$ Critical Care Unit, Hospital de Clínicas de Porto Alegre, Universidade Federal do Rio Grande do Sul, Rua Ramiro Barcelos 2350, 90035-003, Porto Alegre, RS, \\ Brazil \\ b Universidade Federal do Rio Grande do Sul, Faculdade de Medicina, Rua Ramiro Barcelos 2400, 90035-003, Porto Alegre, RS, Brazil

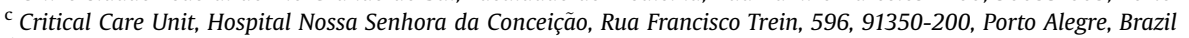 \\ ${ }^{\mathrm{d}}$ Endocrin Division and Medical Nutrition Division, Hospital de Clínicas de Porto Alegre, Universidade Federal do Rio Grande do Sul, Porto Alegre, Brazil
}

\section{A R T I C L E I N F O}

Article history:

Received 6 November 2018

Accepted 28 March 2019

\section{Keywords:}

Nutrition support

Malnourished

Underweight

Critical care

\begin{abstract}
S U M M A R Y
Background \& aims: Critically ill patients with body mass index (BMI) $<20 \mathrm{~kg} / \mathrm{m}^{2}$ have worse outcomes than normal/overweight patients possibly because underweight is a marker of malnutrition. To assess the effects of nutrition therapy in this population during the first week of an ICU stay.

Methods: Prospective, 2-centre, observational study. Nutritional evaluations were performed between days 2 and 3 (first) and between days 5 and 7 (second) of ICU admission. In the first evaluation, patients were divided into non-fed (without nutritional support) and early-fed (those already receiving nutritional support) groups. In the second evaluation, patients were divided according to caloric intake ( $\geq$ or $<20 \mathrm{kcal} / \mathrm{kg}$ ) and protein intake ( $\geq$ or $<1.3 \mathrm{~g}$ of protein $/ \mathrm{kg}$ ).

Results: Of the 4236 patients screened and 342 were included in the cohort. Mortality was 58.5\% (median 21 [11-38.25] days of follow-up). Unadjusted patient survival was worse in the non-fed group than in the early-fed group ( $\mathrm{HR} 1.66 ; 95 \% \mathrm{Cl}, 1.18$ to 2.32). There was no difference in mortality between groups after adjusting for the SOFA score on the day of the evaluation. At the second evaluation, unadjusted analysis showed better in-hospital survival in patients with higher caloric (HR0.58; $95 \% \mathrm{CI}$, 0.40 to 0.86 ) and protein intake (HR0.59; $95 \% \mathrm{CI}, 0.42$ to 0.82 ); there was no association between mortality and caloric or protein intake after adjusting for the SOFA score on the day of the evaluation.

Conclusion: Nutritional therapy in the first week of ICU stay did not affect vital outcome after adjusting for the SOFA score on the day of the evaluation in underweight critically ill patients.

Clinical trial registry: ClinicalTrials.gov number NCT03398343.
\end{abstract}

(ㄷ) 2019 Elsevier Ltd and European Society for Clinical Nutrition and Metabolism. All rights reserved.

\section{Introduction}

Undernutrition, defined as a state of altered body composition and body cell mass resulting from a lack of uptake or intake of nutrition that leads to diminished physical and mental function and impaired outcomes from disease [1], affects up to 65\% of hospitalized patients [2,3]. Malnutrition can make a person more

Abbreviation list: APACHE II score, Acute Physiology and Chronic Health Evaluation II; BMI, body mass index; HR, hazard ratio; ICU, intensive care unit; NUTRIC Nutrition Risk in Critically Ill score; SAPS 3, Simplified Acute Physiology Score 3; SD, standard deviation; SOFA score, Sequential organ failure assessment score.

* Corresponding author. Fax: +55 5133598777.

E-mail addresses: marivv1981@gmail.com (M.V.Viana), analaurajtavares@gmail. com (A.L. Tavares), luizaazevedogross@gmail.com (L.A. Gross), ttonietto@hcpa.edu. br (T.A. Tonietto), vicentelobatoc@gmail.com (V.L. Costa), rbmoraes@hcpa.edu.br (R.B. Moraes), lviana@hcpa.edu.br (M.J. Azevedo), lviana@hcpa.edu.br (L.V. Viana). susceptible to infection, and infection also contributes to malnutrition, which leads to a vicious cycle [2]. Malnutrition is robustly associated with death in critically ill patients [4]. A body mass index (BMI) lower than $20 \mathrm{~kg} / \mathrm{m}^{2}$ has been associated with poorer survival in critically ill patients, probably because of its role as a marker of nutritional status $[5,6]$.

Malnourished patients incur higher costs than nonmalnourished patients, with an increase ranging between $45 \%$ and $102 \%$ [7]. Adequate nutritional therapy in hospitalized malnourished patients might be a cost-saving measure, with one study estimating the potential savings to be on the order of 250 million euros per year [8]. Despite this evidence, cohort studies show that nearly $60 \%$ of malnourished patients do not receive any nutritional treatments [8-10].

Nutritional support in critically ill patients aims to reduce catabolism, attenuate muscle wasting and maintain nutritional 
status [11]. Not all critically ill patients, however, will derive the same benefit from nutritional therapy [11,12]. Patients with moderate to severe nutrition risk might benefit from more aggressive nutritional therapy [13]. However, they may also have more risk of complications from such therapy, including refeeding syndrome [14]. Most guidelines are unable to define when and how to feed malnourished critically ill patients (Table 1) [15-19]. Whether feeding interventions improve clinical outcomes in patients with pre-existing malnutrition (BMI $<20 \mathrm{~kg} / \mathrm{cm}^{2}$ ) is unknown.

We hypothesized that underweight critically ill patients (BMI $<20 \mathrm{~kg} / \mathrm{cm}^{2}$ ) would benefit from early feeding and higher protein and caloric intake during the first week of ICU admission. We evaluated the impact of nutritional therapy on in-hospital mortality in underweight critically ill patients.

\section{Methods}

We conducted a prospective, two-centre (Hospital de Clínicas de Porto Alegre and Hospital Nossa Senhora da Conceição), observational study in underweight critically ill patients (Supplemental Fig. 1). Between October 2015 and August 2017, all patients admitted to intensive care were screened for study eligibility. Patients with a BMI $<20 \mathrm{~kg} / \mathrm{m}^{2}$ were consecutively enrolled. Exclusion criteria were readmission, age less than 18 years, pregnancy, life expectancy less than 24 hours, exclusive oral intake, and exclusive palliative care.

For every included patient, the following data were recorded at ICU admission: age, sex, weight, height, admission category (surgical vs. medical), comorbidities, history of weight loss, primary admission diagnosis, Acute Physiology and Chronic Health Evaluation II (APACHE II) score [20] Simplified Acute Physiology Score 3 (SAPS 3) [21], Sequential Organ Failure Assessment (SOFA) score [22], and Nutrition Risk in Critically Ill (NUTRIC) score [23]. Height (actual or estimated) and weight at admission (estimated or actual weight) were used to calculate BMI [i.e., weight $(\mathrm{kg}) /$ height $\left(\mathrm{m}^{2}\right)$ ]. We performed two evaluations to assess protein and caloric intake as suggested by the 2016 ASPEN guidelines [17]. The first occurred between days 2 and 3 of ICU admission, and the second occurred between days 5 and 7 of ICU admission. At each evaluation, we recorded the type and amount of nutrition received in the previous
24 hours, non-nutritional calories administered (glucose infusions and propofol), and contraindications for enteral nutrition. We also recorded the use of vasopressor, mechanical ventilation, or renal replacement therapies as well as serum electrolytes (potassium, magnesium, phosphorus) and the SOFA score at each evaluation. If patients resumed exclusively oral intake, if palliative care was instituted, or if patients were discharged, the second evaluation was not performed. Nutritional support was prescribed by the assistant staff members and usually aimed for a caloric target of $20-25 \mathrm{kcal} / \mathrm{kg} /$ day and a protein target of $1.2-1.5 \mathrm{~g} / \mathrm{kg} /$ day [17].

We followed patients until hospital discharge. During the hospital stay, we assessed the successful weaning of mechanical ventilation (defined as successful extubation for more than 48 hours) and the presentation of refeeding syndrome (defined by the assistant physician and requiring intervention). The primary outcome was in-hospital mortality. Secondary outcomes were the duration of mechanical ventilation, length of ICU stay, and rate of refeeding syndrome.

\subsection{Ethics}

The study protocol was approved by the ethics committee of the Hospital de Clínicas de Porto (number AGH-USE 2015-0261) Alegre and the Hospital Nossa Senhora da Conceição (number CAAE 45677715.2.3001.5530). This study was registered with ClinicalTrials.gov, number NCT03398343.

\subsection{Statistics}

Statistical analyses were performed using SPSS 20 and R 3.4.0 (R Foundation for Statistical Computing, Vienna, Austria). Descriptive data are reported as the mean $\pm \mathrm{SD}$, median (interquartile range) or frequency (percentage). Non-normally distributed variables were compared using Mann-Whitney U tests. The chi-square test was used to compare categorical variables. To account for changes in the severity of illness, caloric intake, and protein intake over time, we performed a time-dependent Cox regression model analysis with in-hospital mortality as the outcome variable. We conducted a post hoc exploratory analysis in the subgroups of interest ( $p$ value for $0.05)$.

Table 1

Guideline recommendations for nutritional support in malnourished patients.

\begin{tabular}{|c|c|c|c|}
\hline Guideline (Society) & Year & Recommendation & Observation \\
\hline $\begin{array}{l}\text { Management of severe malnutrition: a manual for } \\
\text { physicians and other senior health workers } \\
\text { (WHO) [15] }\end{array}$ & 1999 & $\begin{array}{l}\text { Recommends a caloric target of } 35-40 \mathrm{kcal} / \mathrm{kg} / \\
\text { day }\end{array}$ & Not specific for critically ill patients. \\
\hline $\begin{array}{l}\text { Early enteral nutrition in critically ill patients } \\
\quad \text { (ESICM) [16] }\end{array}$ & 2017 & $\begin{array}{l}\text { No specific recommendation for previous } \\
\text { malnutrition }\end{array}$ & $\begin{array}{l}\text { Suggests an individualized approach that } \\
\text { considers clinical evolution and comorbidities. }\end{array}$ \\
\hline $\begin{array}{l}\text { Guidelines for the Provision and Assessment of } \\
\text { Nutrition Support Therapy in the Adult } \\
\text { Critically Ill Patient [17] } \\
\text { (ASPEN/SCCM) }\end{array}$ & 2016 & $\begin{array}{l}\text { Recommends advancing enteral feeding towards } \\
\text { goal as quickly as tolerated over } 24-48 \text { hours and } \\
\text { achieving more than } 80 \% \text { of the estimated or } \\
\text { calculated goal energy and protein intake within } \\
48-72 \text { hours. When enteral nutrition is not } \\
\text { feasible, suggests initiating exclusively parenteral } \\
\text { nutrition as soon as possible following ICU } \\
\text { admission. }\end{array}$ & Suggests monitoring refeeding syndrome. \\
\hline $\begin{array}{l}\text { Surviving Sepsis Campaign: International } \\
\text { Guidelines for Management of Sepsis and } \\
\text { Septic Shock [18] } \\
\text { (SCCM/ESCIM) }\end{array}$ & 2017 & $\begin{array}{l}\text { Suggests considering initiating parenteral } \\
\text { nutrition early when enteral feeding is not } \\
\text { feasible. }\end{array}$ & $\begin{array}{l}\text { States that there is a lack of evidence with } \\
\text { malnourished patients since they are either } \\
\text { excluded or rarely represented in trials. }\end{array}$ \\
\hline $\begin{array}{l}\text { ESPEN guidelines on clinical nutrition in the } \\
\text { intensive care unit [19] } \\
\text { (ESPEN) }\end{array}$ & 2018 & $\begin{array}{l}\text { Early and progressive PN can be provided instead } \\
\text { of no nutrition in case of contraindications for EN } \\
\text { in severely malnourished patients. }\end{array}$ & $\begin{array}{l}\text { States that the recommendation is based on } \\
\text { expert opinion because randomized studies are } \\
\text { not available due to the ethical dilemma } \\
\text { preventing the conduct of subject to further } \\
\text { starvation as a consequence of tentative study } \\
\text { designs or omitting an intervention with a strong } \\
\text { physiological rationale. }\end{array}$ \\
\hline
\end{tabular}


For the first evaluation, we divided the sample of patients into those who received nutritional support, either parenteral, enteral or both (early-fed group), and those who did not receive nutritional support (non-fed group). In the second evaluation, we divided the sample according to protein target $(1.3 \mathrm{~g} / \mathrm{kg} /$ day $)$ and caloric target (20 kcal/kg/day). A Cox regression analysis was performed for both evaluations with in-hospital mortality as the outcome. The analyses of in-hospital survival were adjusted for SAPS3, NUTRIC, and SOFA severity scores on the day of the evaluation.

\section{Results}

\subsection{Patient profiles and overall mortality}

Between October 2015 and August 2017, 4236 adult patients were acutely admitted into the ICUs (mean of 193 patients/month). The prevalence of BMIs lower than $20 \mathrm{~kg} / \mathrm{m}^{2}$ was $16.3 \%$. Figure 1 shows the study diagram. A total of 342 patients were included, of whom 203 (59.4\%) were men, 205 (59.9\%) had a BMI lower than $18.5 \mathrm{~kg} / \mathrm{m}^{2}$, and $185(54 \%)$ had high NUTRIC scores. The mean SAPS3 score was $68.53 \pm 13.9$.

The in-hospital mortality rate was $58.5 \%$ over a median of 21 $(11-38.25)$ days of follow-up. There was a reduction in SOFA scores (5 [3-8] to 4 [2-6], p < 0.001 ) between the 1 st and 2 nd evaluations. Moreover, there was an increase in caloric (18.07
[9.84-26.14] to 26.23 [20.50-30.36], $\mathrm{p}<0.001)$ and protein $(0.89$ [0.30-1.40] to 1.42 [1.05-1.63], $\mathrm{p}<0.001$ ) intake between the $1 \mathrm{st}$ and 2nd evaluations. A total of 558 evaluations of protein and caloric intake were performed. In time-dependent multivariate Cox regression model [HR, 95\%] with mortality as the outcome, there were no differences for protein (0.97 [0.78-1.20]) or caloric intake (1.00 [0.99-1.16]) when adjusted for the SOFA score (1.13 [1.10-1.73]). A $100 \%$ power was detected in a post hoc analysis for protein and calories.

\subsection{First evaluation: non-fed versus early-fed}

In the first evaluation, 62 (18.13\%) patients did not receive nutritional support (non-fed group). The remaining 280 patients received nutritional support (early-fed group) as follows: 272 (79.5\%), enteral support; 5 (1.5\%), total parenteral nutrition; and 3 (0.9\%), supplemental parenteral support. The caloric target of $20 \mathrm{kcal} / \mathrm{kg} /$ day was achieved by 149 (43.6\%) patients, and the protein target of $1.3 \mathrm{~g} / \mathrm{kg} /$ day by 109 (31.9). Table 2 lists the characteristics of all study patients and compares the non-fed group and the early-fed group. Sixty-eight patients had some contraindications for enteral feeding, mainly haemodynamic instability (37 patients). Figure 2 - Panel A shows the four Cox regression models used to assess the relationship between nutritional support (earlyfed versus non-fed groups) and in-hospital mortality. A post hoc

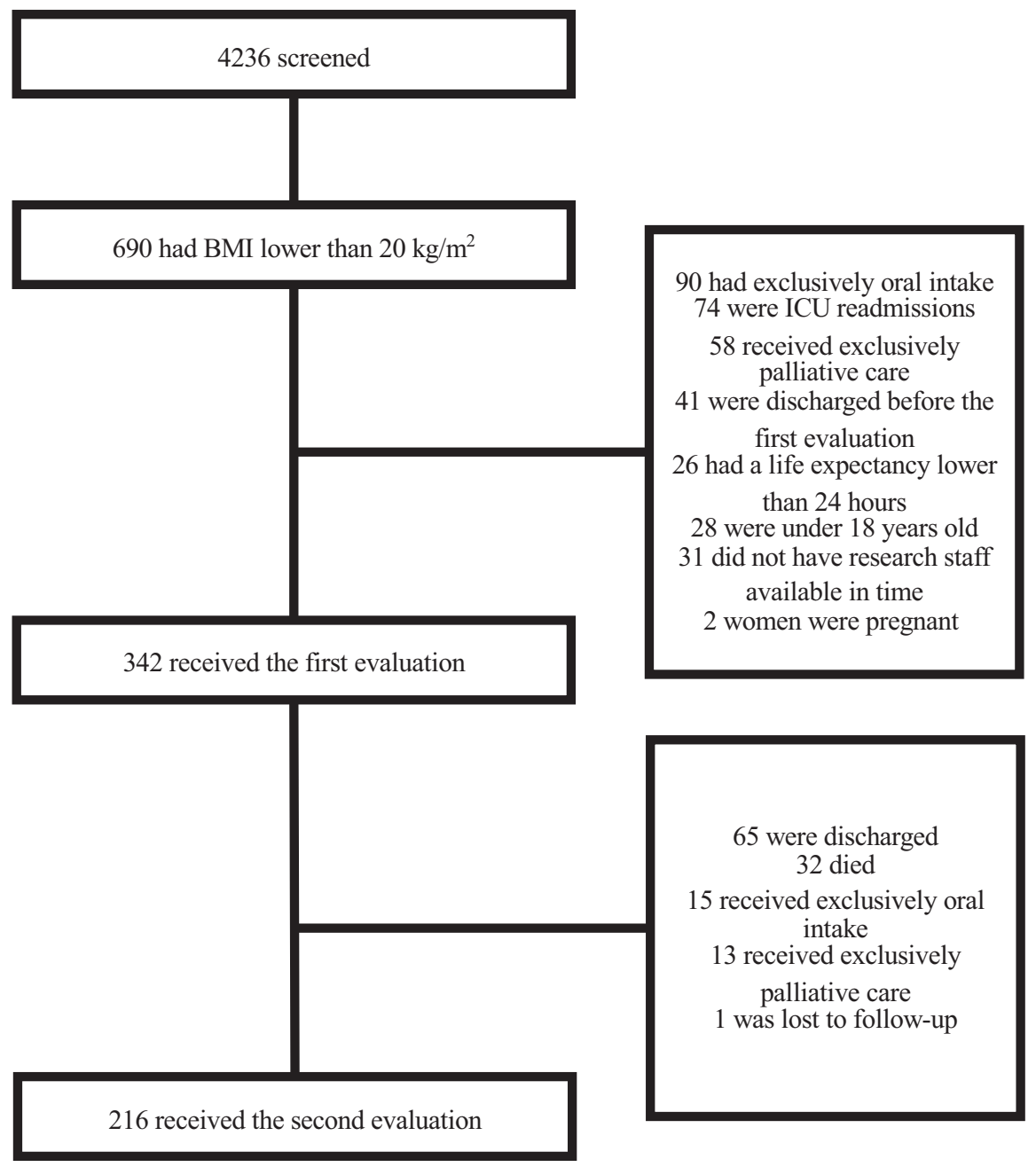

Fig. 1. Shows the screening, assessments and follow-ups included in the study and the reasons for exclusion. 
Table 2

Patients characteristics and outcomes at the first evaluation based on nutrition support.

\begin{tabular}{|c|c|c|c|}
\hline \multirow[t]{2}{*}{ Patients characteristics and outcomes } & \multirow{2}{*}{$\begin{array}{l}\text { Non-fed group } \\
\mathrm{n}=62\end{array}$} & \multirow{2}{*}{$\frac{\text { Early-fed group }}{\mathrm{n}=280}$} & \multirow[t]{2}{*}{$\mathrm{P}$} \\
\hline & & & \\
\hline Age (years) & $54.63 \pm 17.55$ & $53.89 \pm 17.28$ & 0.762 \\
\hline Men (\%) & $34(54.8)$ & $169(60.4)$ & 0.423 \\
\hline Weight (kg) & $47.69 \pm 7.95$ & $47.91 \pm 8.13$ & 0.852 \\
\hline BMI $\left(\mathrm{kg} / \mathrm{m}^{2}\right)$ & $18.09[16.68-19.12]$ & $18.07[16.33-19.12]$ & 0.778 \\
\hline History of weight loss prior ICU admission (\%) & $21(33.9)$ & $95(33.9)$ & 0.517 \\
\hline Temporal muscle wasting (\%) & $31(59.4)$ & $152(54.4)$ & 0.489 \\
\hline \multicolumn{4}{|l|}{ Pre-existing illness at ICU admission } \\
\hline Chronic renal failure (\%) & $4(6.5)$ & $18(6.4)$ & 0.995 \\
\hline Cardiac failure (\%) & $5(8.1)$ & $21(7.5)$ & 0.885 \\
\hline Respiratory (\%) & $5(8.1)$ & $58(20.7)$ & 0.020 \\
\hline Cancer $(\%)$ & $16(25.8)$ & $55(19.6)$ & 0.279 \\
\hline Liver disease $(\%)$ & $10(16.1)$ & $12(4.3)$ & 0.001 \\
\hline Acquired immunodeficiency syndrome (\%) & $13(21)$ & $70(25)$ & 0.503 \\
\hline Medical diagnosis at ICU admission & $46(74.2)$ & $255(91.1)$ & $<0.001$ \\
\hline Days in hospital prior to ICU admission & $3.5[1-13.25]$ & $4[1-12]$ & 0.685 \\
\hline NUTRIC & $5[4-6.25]$ & $5[3-6]$ & 0.035 \\
\hline SAPS3 & $70.60 \pm 16.66$ & $68.26 \pm 12.75$ & 0.266 \\
\hline SOFA at admission & $7[5-11]$ & $6[4-8]$ & 0.022 \\
\hline \multicolumn{4}{|l|}{ Main reason for ICU admission } \\
\hline Respiratory failure & $15(24.2)$ & $122(43.7)$ & $<0.001$ \\
\hline Sepsis & $25(40.3)$ & $85(30.5)$ & \\
\hline Neurological & $3(4.8)$ & $39(14)$ & \\
\hline Cardiovascular & $6(9.7)$ & $14(5)$ & \\
\hline Major surgery & $12(19.4)$ & $14(5)$ & \\
\hline SOFA at first evaluation & $7[4-11]$ & $5[2-7]$ & $<0.001$ \\
\hline \multicolumn{4}{|l|}{ At first evaluation } \\
\hline Vasopressor (\%) & $43(69.4)$ & $114(40.7)$ & $<0.001$ \\
\hline Renal replacement therapy (\%) & $25(40.3)$ & $44(15.7)$ & $<0.001$ \\
\hline Mechanical ventilation (\%) & $51(82.3)$ & $222(79.3)$ & 0.598 \\
\hline Potassium at first evaluation (mEq/L) & $3.99 \pm 0.71$ & $4.02 \pm 0.71$ & 0.724 \\
\hline Magnesium at first evaluation (mg/dl) & $2.06 \pm 0.59$ & $2.05 \pm 0.48$ & 0.892 \\
\hline Phosphorus at first evaluation (mg/dl) & $2.97 \pm 1.02$ & $3.16 \pm 1.44$ & 0.420 \\
\hline \multicolumn{4}{|l|}{ Outcomes } \\
\hline Refeeding syndrome (\%) & $0(0)$ & $6(2.3)$ & 0.261 \\
\hline Duration of mechanical ventilation & $7[4-12.5]$ & $8[4-15]$ & 0.806 \\
\hline Length of ICU stay (days) & $8[5-16.25]$ & $10[6-17.75]$ & 0.182 \\
\hline Length of hospital stay (days) & 17 [7.75-29] & $22[12-40.75]$ & 0.021 \\
\hline ICU mortality (\%) & $30(48.4)$ & $103(36.8)$ & 0.090 \\
\hline Hospital mortality (\%) & $44(71)$ & $156(55.7)$ & 0.027 \\
\hline
\end{tabular}

Values are reported as the mean \pm SD, median [interquartile ranges] or numbers (\%). SOFA - sequential organ failure assessment. ICU - intensive care unit.

analysis detected a power of $99 \%$ for the model adjusted for SOFA scores on the day of the evaluation.

\subsection{Second evaluation: protein and caloric intake}

A total of 216 patients completed the second evaluation; of these, 10 (4.6\%) did not receive nutritional therapy, 202 (93.5\%) received enteral nutrition, $1(0.5 \%)$ received parenteral nutrition, and 3 (1.4) received both parenteral and enteral nutrition. The caloric target of $20 \mathrm{kcal} / \mathrm{kg} /$ day was achieved by 165 (76.4\%) patients, and the protein target of $1.3 \mathrm{~g} / \mathrm{kg} /$ day by 126 (58.3\%) at the second evaluation. Table 3 shows the characteristics of patients in the second evaluation according to caloric and protein targets.The relationship between protein intake, caloric intake and in-hospital survival at the second evaluation was evaluated with different models (Fig. 2 - Panel B and Panel C). The protective effect of achieving the nutritional support target was lost when data were adjusted for SOFA score on the day of the second evaluation. A post hoc analysis detected a power of $99 \%$ for the model adjusted for SOFA scores on the day of the evaluation. There was also no difference after adjustment for SOFA score on the day of the evaluation comparing those patients that achieved both caloric and protein targets and those that did not reached both targets $(\mathrm{p}=0.173)$.

\subsection{Secondary outcomes and subgroup analysis}

In the first evaluation, there were no differences in the duration of mechanical ventilation therapy or the length of ICU stay between the non-fed and the early-fed groups. In a Cox regression model, protein intake at the second evaluation was not associated with successful weaning. There was also no association between protein intake at the second evaluation and being discharged from the ICU. There was a total of $6(1.8 \%)$ patients diagnosed with refeeding syndrome, but we found no association between this diagnosis and the number of calories received. There was a total of 5 measures of phosphorus below $0.5 \mathrm{mg} / \mathrm{dl}$ and no significant association with nutritional support. There was no difference regarding nutritional therapy between the studies sites. Subgroup analyses showed no significant interaction of in-hospital mortality with BMI ( $\geq$ or $<$ than $18.5 \mathrm{~kg} / \mathrm{cm}^{2}$ ), age ( $\geq$ or less $<70$ years), or NUTRIC score ( $\geq$ or $<5$ points) at the first evaluation (non-fed versus early-fed).

\section{Discussion}

This study was designed to address a real-life dilemma: how to feed underweight critically ill patients. In this prospective observational study, which is, to our knowledge, the largest cohort study of underweight critically ill patients, we demonstrated that there was no difference in in-hospital mortality based on the timing of 

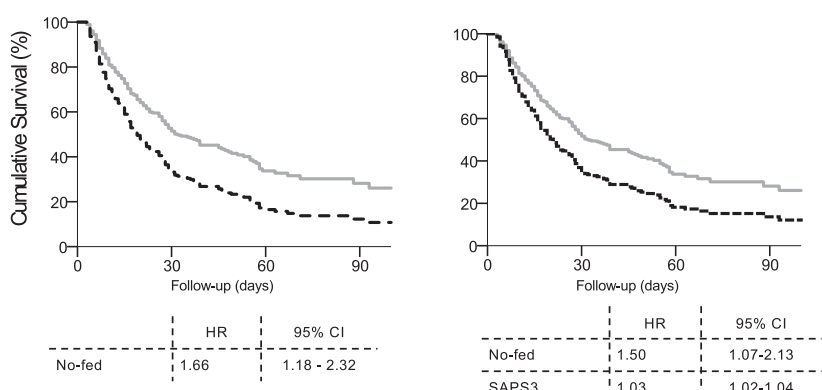

Panel A
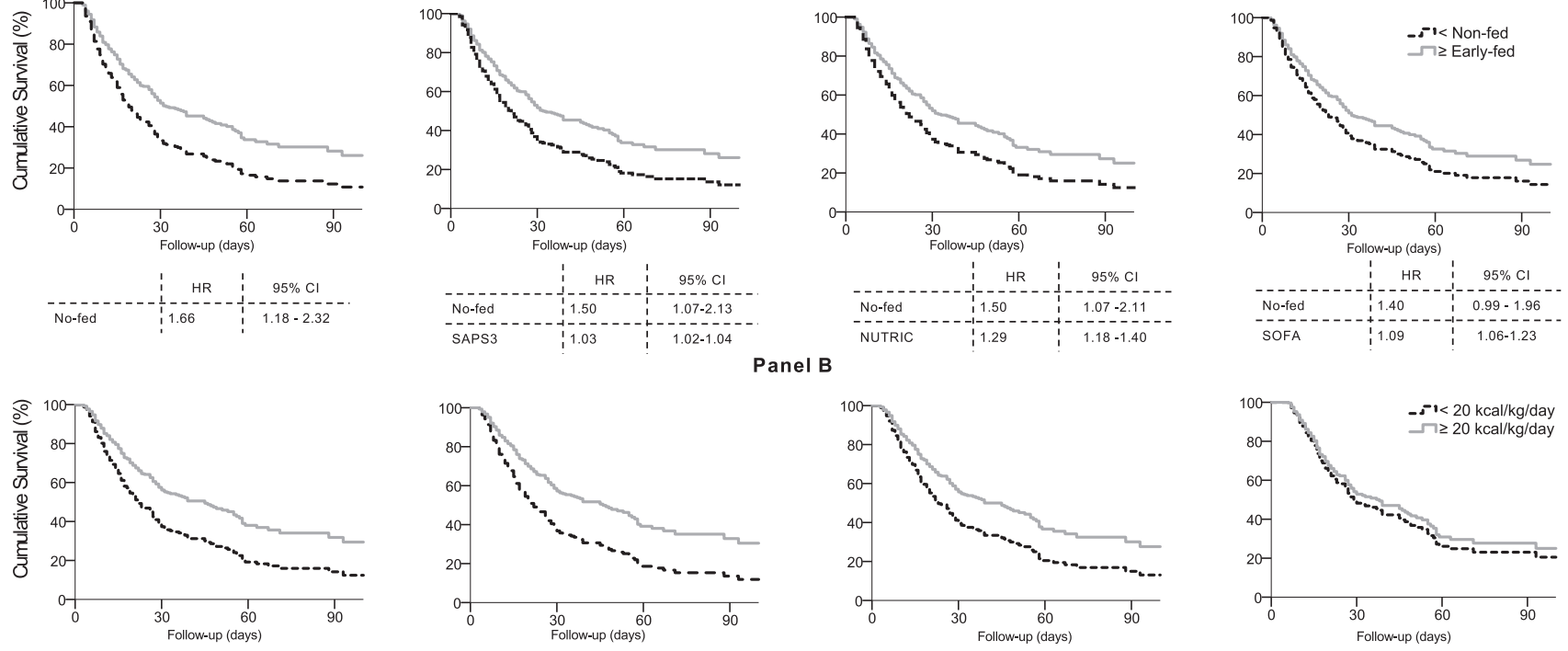

Panel B
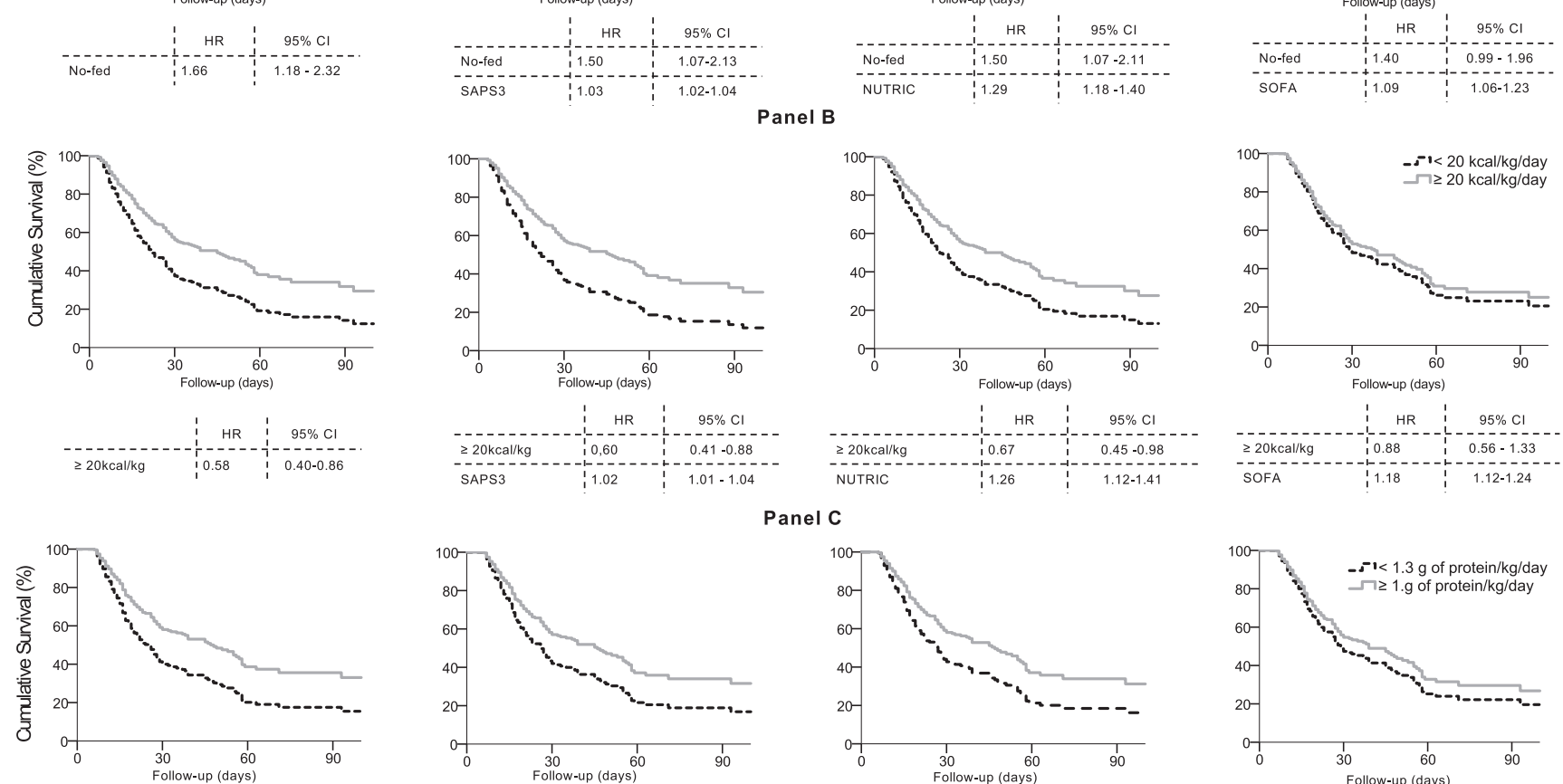

Panel C
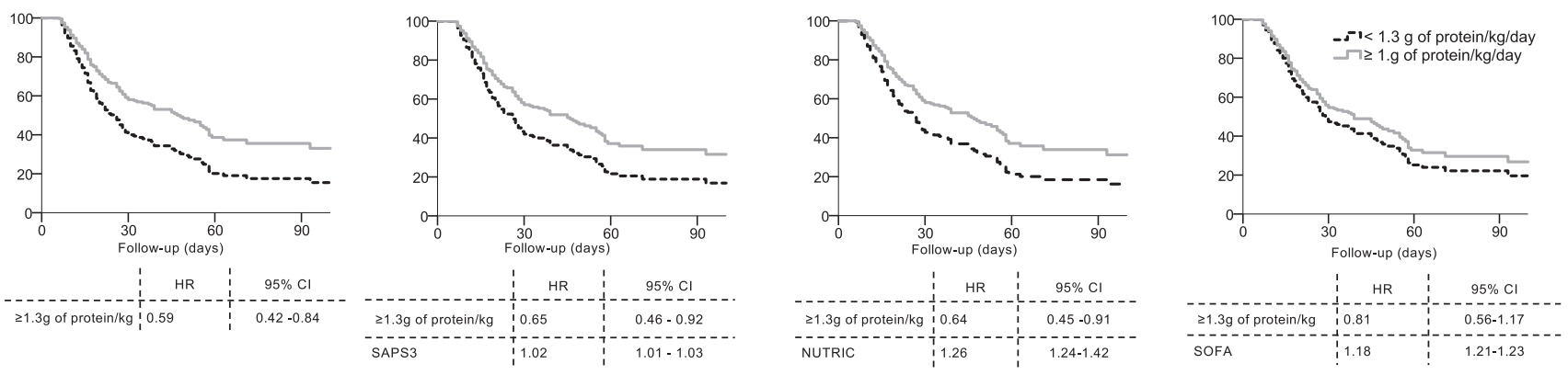

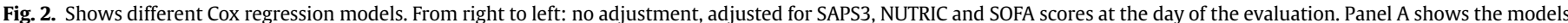

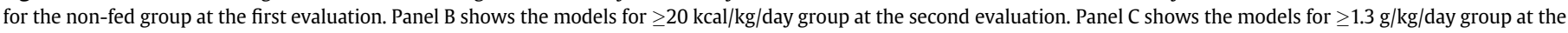
second evaluation.

the initiation of nutritional support or the amount of energy and protein provided during the first week of ICU stay when adjusted for the severity of the illness on the day of the evaluation.

The optimal timing, amount, and route of nutritional support in critically ill patients are controversial, especially in underweight patients [14,24], mainly because these patients have been underrepresented or excluded from previous studies [25-28]. In addition to the unique population we evaluated, our study diverges from previous observational and randomized trials for other reasons. First, we evaluated caloric and protein intake at two distinct

Table 3

Patient characteristics and outcomes at the second evaluation based on protein and calorie targets.

\begin{tabular}{|c|c|c|c|c|c|c|}
\hline \multirow[t]{2}{*}{ Patient characteristics and outcomes } & \multicolumn{3}{|l|}{ Protein target } & \multicolumn{3}{|l|}{ Calorie target } \\
\hline & $<1.3 \mathrm{~g} / \mathrm{kg} /$ day $\mathrm{n}=90$ & $\geq 1.3 \mathrm{~g} / \mathrm{kg} /$ day $\mathrm{n}=126$ & $\mathrm{p}$ & $<20 \mathrm{kcal} / \mathrm{kg} /$ day $\mathrm{n}=51$ & $\geq 20 \mathrm{kcal} / \mathrm{kg} /$ day $\mathrm{n}=165$ & $\mathrm{p}$ \\
\hline SOFA & $5[3-8.5]$ & $3[2-5]$ & $<0.001$ & $5[3-9]$ & $3[2-6]$ & 0.001 \\
\hline Vasopressor & $34(38.2)$ & $21(16.5)$ & $<0.001$ & $25(49)$ & $30(18.2)$ & $<0.001$ \\
\hline Renal replacement therapy (\%) & $30(33.3)$ & $19(15.1)$ & 0.002 & $15(29.4)$ & $34(20.6)$ & 0.189 \\
\hline Mechanical ventilation (\%) & $72(80.0)$ & $84(66.7)$ & 0.031 & $42(82.4)$ & $114(69.1)$ & 0.065 \\
\hline Refeeding syndrome (\%) & $3(3.4)$ & $3(2.5)$ & 0.691 & $1(2)$ & $5(3.1)$ & 0.691 \\
\hline Potassium $(\mathrm{mEq} / \mathrm{L})$ & $4.07 \pm 0.85$ & $4.05 \pm 0.73$ & 0.334 & $3.94 \pm 0.74$ & $4 \pm 0.75$ & 0.218 \\
\hline Magnesium (mg/dl) & $2.10 \pm 0.43$ & $2.09 \pm 0.51$ & 0.775 & $2.13 \pm 0.44$ & $2.08 \pm 0.49$ & 0.551 \\
\hline Phosphorus (mg/dl) & $3.06 \pm 1.74$ & $2.87 \pm 1.14$ & 0.155 & $3.10 \pm 0.44$ & $2.08 \pm 0.49$ & 0.551 \\
\hline Duration of ventilation (days) & $7[4-14]$ & $10[6-18.25]$ & 0.001 & 11 [7-19] & $11[6-20]$ & 0.845 \\
\hline Length of ICU stay (days) & $7.5[5-13.25]$ & $15[10-23]$ & $<0.001$ & $12[9-22]$ & $15[10-23]$ & 0.126 \\
\hline Length of hospital stay (days) & $17[9-29]$ & $29[17-53.75]$ & $<0.001$ & $20[14-30]$ & $28[16-49]$ & 0.012 \\
\hline ICU mortality (\%) & $43(47.8)$ & $44(34.9)$ & 0.058 & $24(47.1)$ & $63(38.1)$ & 0.259 \\
\hline Hospital mortality (\%) & $61(67.8)$ & $73(58.3)$ & 0.142 & $36(70.6)$ & $98(59.4)$ & 0.159 \\
\hline
\end{tabular}

Values are reported as the mean $\pm \mathrm{SD}$, median [interquartile ranges] or numbers (\%). SOFA - sequential organ failure assessment. ICU - intensive care unit. 
periods of time, and second, we adjusted the effect of nutritional support based on the severity of the illness at the day of the evaluation. Most observational studies have used the mean caloric and protein intake over time and adjusted these values based on the illness severity scores calculated at the time of admission [29-31]. This approach does not consider dynamic changes in the severity of an illness, which might influence nutritional intake. We demonstrated that there was a significant difference in hospital mortality between the non-fed and early-fed groups and between those receiving higher and lower protein intake at the second evaluation after adjustment for the SAPS3 score, but this difference was lost after adjustment for the SOFA score at the day of the evaluation. The SOFA score on the day of the evaluation reflects the real-time severity of the condition of our patients. In fact, a considerable proportion of patients was being treated with vasopressor therapy at the first and second evaluations in our study. Although observational data show that it is safe to start enteral feeding while patients are receiving vasopressor therapy [32-34], the recent NUTRIREA-2 trial showed that this combination can lead to a greater risk of digestive complications [35]. Regrettably, we did not measure these complications.

Unfortunately, we could not establish a clear benefit of nutritional support in malnourished patients. It is worthwhile to highlight that our study had an observational design, and feeding strategies were defined by the assistant physician. No intervention was applied, and ideal targets, especially for protein, were achieved in slightly more than half of the patients at the second evaluation. In the subgroup analysis there was no interaction between those with high or low NUTRIC score and nutrition therapy, demonstrating that the effect of nutrition therapy was not different across the stratum of NUTRIC score.

On the other hand, it should be emphasized that there was no harm in enhancing nutritional therapy in the first week. The refeeding Syndrome Trial showed an increased survival with caloric restriction compared to standard nutrition [36]. However, we did not observe a difference in the incidence of refeeding syndrome and electrolyte disturbances based on nutritional support [37]. Refeeding syndrome was defined by the attending physician because there is a lack of a universally accepted definition [38,39]. We also analysed those patients that had phosphorus lower than $0.5 \mathrm{mg} / \mathrm{dl}$ and found no association with nutrition support.

To identify malnourished patients, we used a BMI lower than $20 \mathrm{~kg} / \mathrm{m}^{2}$, which has been associated with poorer survival rates in critically ill patients than higher BMIs [5]. In addition, similar definitions and cut-off points were described in other studies $[29,40]$. We are aware of the limitations of using BMI to estimate body fat and lean mass at the individual level. It is possible that some of the included patients had a higher lean body mass composition but were not malnourished [41]. However, we have other clinical data in addition to the BMI values that support the claim that the vast majority of the patients included in this study were undernourished: $33.9 \%$ of the patients had a history of prior weight loss, $79.2 \%$ of the patients had temporal muscle wasting, and $79.8 \%$ of the patients had pre-existing illness, all of which corroborate the diagnosis of malnourishment in the patients evaluated in our study. We also performed sensitivity analyses including only patients with a $\mathrm{BMI}<18.5 \mathrm{~kg} / \mathrm{m}^{2}$, and the main results were unaffected.

Our study has some limitations. First is the observational design of the study. Observational data, particularly in the field of ICU nutrition, should be interpreted with caution, since the clinical course can affect nutritional intake more than nutrition can affect outcomes [42]. However, we attempted to minimize this interference by adjusting the findings based on the severity of the illness at the time of the patient's evaluation rather than on admission scores. Second, there were very few patients who received parenteral nutrition. Although this precludes any conclusions regarding the possible benefits of early parenteral nutrition or supplemental parenteral nutrition in this population, it is a finding that is consistent with a reduction in the prescription of parenteral nutrition [42] and the guidelines that favour early enteral nutrition $[16,17]$. Moreover, recent randomized trials and meta-analysis have failed to show a benefit of parenteral nutrition over enteral nutrition $[24,42,43]$. A post hoc of the PERMIT trial could not show benefit of moderate versus full caloric feeding in patients with high nutritional risk defined either by NUTRIC score, BMI and prealbumin. Also, for undernourished critically ill children, withholding parenteral nutrition in the first week was clinically superior to early parenteral nutrition [44].There was also no difference in electrolytes between permissive underfeeding and standard feeding [45].

The existing guidelines do not provide recommendations for malnourished critically ill patients based on sound evidence $[17,18]$ because of a lack of available data. Although we cannot provide definitive answers on how to nourish critically ill underweight patients, our study certainly helps to fill this evidence gap by providing new and important guidance for this population. Additionally, by showing no harm in enhancing nutritional therapy in these patients, this study contributes to the future directions of nutrition research and to the inclusion of this specific group of patients in future randomized trials.

\section{Conclusion}

Enhanced nutritional therapy in the first week of an ICU stay for underweight critically ill patients was not clearly associated with better in-hospital survival or changes in complications such as refeeding syndrome and electrolyte disturbances in the current study. Further studies are needed to establish how to optimize nutrition for these patients.

\section{Author contributions}

MVV, LVV and MJA designed the research. MVV, ALT, VLC, LAG, TAT and RBM conducted the research. MVV and LVV analyzed data and performed the statistical analyses. All authors contributed substantially with the writing of the manuscript. MVV and LVV had full access to all of the data in the study and take responsibility for the integrity of the data and the accuracy of the data analysis. This manuscript is dedicated to the memory of our dear friend, colleague and co-author Mirela Jobim de Azevedo who tragically passed away in May 2017.

\section{Conflicts of interest}

The authors have no conflicts of interest to declare.

\section{Funding sources}

The study was supported by a grant from Fundação de Amparo a Pesquisa do Rio Grande do Sul (FAPERGS), Conselho Nacional de Desenvolvimento Científico e Tecnológico and Fundo de Incetivo a Pesquisa e Eventos do Hospital de Clínicas de Porto Alegre.

\section{Meeting presentations}

Selected data from this article were partially presented at 29th European Society of Intensive Care Medicine Congress (ESICM Lives); Milan, Italy 2016; 39th European Society of Parenteral and Enteral Nutrition (ESPEN), Hague, Netherlands 2017; 13th World 
Federation of Societies of Intensive and Critical Care Medicine (WFSICCM), Rio de Janeiro, Brazil 2017.

\section{Appendix A. Supplementary data}

Supplementary data to this article can be found online at https://doi.org/10.1016/j.clnu.2019.03.038.

\section{References}

[1] Cederholm T, Bosaeus I, Barazzoni R, Bauer J, Van Gossum A, Klek S, et al. Diagnostic criteria for malnutrition - an ESPEN consensus statement. Clin Nutr 2015;34(3):335-40.

[2] Katona P, Katona-Apte J. The interaction between nutrition and infection. Clin Infect Dis 2008;46(10):1582-8.

[3] Klek S, Krznaric Z, Gundogdu RH, Chourdakis M, Kekstas G, Jakobson T, et al. Prevalence of malnutrition in various political, economic, and geographic settings. J Parenter Enteral Nutr 2015;39(2):200-10.

[4] Mogensen KM, Robinson MK, Casey JD, Gunasekera NS, Moromizato T, Rawn JD, et al. Nutritional status and mortality in the critically ill. Crit Care Med 2015;43(12):2605-15.

[5] Viana MV, Moraes RB, Fabbrin AR, Santos MF, Torman VB, Vieira SR, et al. Contrasting effects of preexisting hyperglycemia and higher body size on hospital mortality in critically ill patients: a prospective cohort study. BMC Endocr Disord 2014;14:50.

[6] Tremblay A, Bandi V. Impact of body mass index on outcomes following critical care. Chest 2003;123(4):1202-7.

[7] Gastalver-Martin C, Alarcon-Payer C, Leon-Sanz M. Individualized measure ment of disease-related malnutrition's costs. Clin Nutr 2015;34(5):951-5.

[8] Henriksen C, Gjelstad IM, Nilssen H, Blomhoff R. A low proportion of malnourished patients receive nutrition treatment - results from nutritionDay. Food Nutr Res 2017;61(1):1391667.

[9] Waitzberg DL, Caiaffa WT, Correia MI. Hospital malnutrition: the Brazilian national survey (IBRANUTRI): a study of 4000 patients. Nutrition 2001; 17(7-8):573-80.

[10] Heyland DK, Dhaliwal R, Wang M, Day AG. The prevalence of iatrogenic underfeeding in the nutritionally 'at-risk' critically ill patient: results of an international, multicenter, prospective study. Clin Nutr 2015;34(4):659-66.

[11] Bear DE, Wandrag L, Merriweather JL, Connolly B, Hart N, Grocott MPW, et al. The role of nutritional support in the physical and functional recovery of critically ill patients: a narrative review. Crit Care 2017;21(1):226.

[12] Sundstrom Rehal M, Tjader I, Wernerman J. Nutritional needs for the critically ill in relation to inflammation. Curr Opin Clin Nutr Metab Care 2016:19(2):138-43.

[13] McClave SA, Martindale RG, Rice TW, Heyland DK. Feeding the critically ill patient. Crit Care Med 2014;42(12):2600-10.

[14] Preiser JC, van Zanten AR, Berger MM, Biolo G, Casaer MP, Doig GS, et al. Metabolic and nutritional support of critically ill patients: consensus and controversies. Crit Care 2015;19:35.

[15] World Health Organization. Management of severe malnutrition: a manual for physicians and other senior health workers. 1999. Access in January 2019: https:/ www.who.int/nutrition/publications/severemalnutrition/9241545119/en/.

[16] Reintam Blaser A, Starkopf J, Alhazzani W, Berger MM, Casaer MP, Deane AM, et al. Early enteral nutrition in critically ill patients: ESICM clinical practice guidelines. Intensive Care Med 2017;43(3):380-98.

[17] McClave SA, Taylor BE, Martindale RG, Warren MM, Johnson DR, Braunschweig C, et al. Guidelines for the provision and assessment of nutrition support therapy in the adult critically ill patient: society of critical care medicine (SCCM) and American society for parenteral and enteral nutrition (A.S.P.E.N.). J Parenter Enteral Nutr 2016;40(2):159-211.

[18] Rhodes A, Evans LE, Alhazzani W, Levy MM, Antonelli M, Ferrer R, et al Surviving sepsis campaign: international guidelines for management of sepsis and septic shock: 2016. Crit Care Med 2017;45(3):486-552.

[19] Singer P, Blaser AR, Berger MM, Alhazzani W, Calder PC, Casaer MP, et al. ESPEN guideline on clinical nutrition in the intensive care unit. Clin Nutr 2019;38:48-79. https://doi.org/10.1016/j.clnu.2018.08.037.

[20] Knaus WA, Draper EA, Wagner DP, Zimmerman JE. Apache II: a severity of disease classification system. Crit Care Med 1985;13(10):818-29.

[21] Moreno RP, Metnitz PG, Almeida E, Jordan B, Bauer P, Campos RA, et al. SAPS 3-From evaluation of the patient to evaluation of the intensive care unit. Part 2: development of a prognostic model for hospital mortality at ICU admission. Intensive Care Med 2005;31(10):1345-55.
[22] Vincent J-L, Moreno R, Takala J, Willatts S, De Mendonça A, Bruining H, et al. The SOFA (Sepsis-related Organ Failure Assessment) score to describe organ dysfunction/failure. Intensive Care Med 1996;22(7):707-10.

[23] Heyland DK, Dhaliwal R, Jiang X, Day AG. Identifying critically ill patients who benefit the most from nutrition therapy: the development and initial validation of a novel risk assessment tool. Crit Care 2011;15(6):R268.

[24] Casaer MP, Van den Berghe G. Nutrition in the acute phase of critical illness. N Engl J Med 2014;370(13):1227-36.

[25] Casaer MP, Mesotten D, Hermans G, Wouters PJ, Schetz M, Meyfroidt G, et al. Early versus late parenteral nutrition in critically ill adults. N Engl J Med 2011;365(6):506-17.

[26] Ibrahim EH, Mehringer L, Prentice D, Sherman G, Schaiff R, Fraser V, et al. Early versus late enteral feeding of mechanically ventilated patients: results of a clinical trial. J Parenter Enteral Nutr 2002;26(3):174-81.

[27] Rice TW, Wheeler AP, Thompson BT, Steingrub J, Hite RD, Moss M, et al. Initial trophic vs full enteral feeding in patients with acute lung injury: the EDEN randomized trial. J Am Med Assoc 2012;307(8):795-803.

[28] Arabi YM, Aldawood AS, Haddad SH, Al-Dorzi HM, Tamim HM, Jones G, et al. Permissive underfeeding or standard enteral feeding in critically ill adults. N Engl J Med 2015;372(25):2398-408.

[29] Alberda C, Gramlich L, Jones N, Jeejeebhoy K, Day AG, Dhaliwal R, et al. The relationship between nutritional intake and clinical outcomes in critically ill patients: results of an international multicenter observational study. Intensive Care Med 2009;35(10):1728-37.

[30] Weijs PJ, Stapel SN, de Groot SD, Driessen RH, de Jong E, Girbes AR, et al. Optimal protein and energy nutrition decreases mortality in mechanically ventilated, critically ill patients: a prospective observational cohort study. J Parenter Enteral Nutr 2012;36(1):60-8.

[31] Weijs PJ, Looijaard WG, Beishuizen A, Girbes AR, Oudemans-van Straaten HM. Early high protein intake is associated with low mortality and energy overfeeding with high mortality in non-septic mechanically ventilated critically ill patients. Crit Care 2014;18(6):701.

[32] Artinian V, Krayem H, DiGiovine B. Effects of early enteral feeding on the outcome of critically ill mechanically ventilated medical patients. Chest 2006;129(4):960-7.

[33] Khalid I, Doshi P, DiGiovine B. Early enteral nutrition and outcomes of critically ill patients treated with vasopressors and mechanical ventilation. Am J Crit Care 2010;19(3):261-8.

[34] Berger MM, Chiolero RL. Enteral nutrition and cardiovascular failure: from myths to clinical practice. J Parenter Enteral Nutr 2009;33(6):702-9.

[35] Reignier J, Boisrame-Helms J, Brisard L, Lascarrou JB, Ait Hssain A, Anguel N, et al. Enteral versus parenteral early nutrition in ventilated adults with shock: a randomised, controlled, multicentre, open-label, parallel-group study (NUTRIREA-2). Lancet 2018;391(10116):133-43.

[36] Doig GS, Simpson F, Heighes PT, Bellomo R, Chesher D, Caterson ID, et al. Restricted versus continued standard caloric intake during the management of refeeding syndrome in critically ill adults: a randomised, parallel-group, multicentre, single-blind controlled trial. Lancet Respir Med 2015;3(12): 943-52.

[37] Kraft MD, Btaiche IF, Sacks GS. Review of the refeeding syndrome. Nutr Clin Pract 2005;20(6):625-33.

[38] Friedli N, Stanga Z, Sobotka L, Culkin A, Kondrup J, Laviano A, et al. Revisiting the refeeding syndrome: results of a systematic review. Nutrition 2017;35: 151-60.

[39] Mehanna HM, Moledina J, Travis J. Refeeding syndrome: what it is, and how to prevent and treat it. BMJ 2008;336(7659):1495-8.

[40] Harvey SE, Parrott F, Harrison DA, Bear DE, Segaran E, Beale R, et al. Trial of the route of early nutritional support in critically ill adults. N Engl J Med 2014:371(18):1673-84.

[41] Gonzalez MC, Correia M, Heymsfield SB. A requiem for BMI in the clinical setting. Curr Opin Clin Nutr Metab Care 2017;20(5):314-21.

[42] Gershengorn HB, Kahn JM, Wunsch H. Temporal trends in the use of parenteral nutrition in critically ill patients. Chest 2014;145(3):508-17.

[43] Tian F, Heighes PT, Allingstrup MJ, Doig GS. Early enteral nutrition provided within 24 hours of ICU admission: a meta-analysis of randomized controlled trials. Crit Care Med 2018;46(7):1049-56.

[44] van Puffelen E, Hulst JM, Vanhorebeek I, Dulfer K, Van den Berghe G, Verbruggen S, et al. Outcomes of delaying parenteral nutrition for 1 Week vs initiation within 24 hours among undernourished children in pediatric intensive care: a subanalysis of the PEPaNIC randomized clinical trial. JAMA Netw Open 2018;1(5):e182668.

[45] Arabi YM, Aldawood AS, Al-Dorzi HM, Tamim HM, Haddad SH, Jones G, et al. Permissive underfeeding or standard enteral feeding in high- and lownutritional-risk critically ill adults. Post hoc analysis of the PermiT trial. Am J Respir Crit Care Med 2017;195(5):652-62. 